\title{
Absorbing the Rapid Growth of Shopping Centres in Poland after the Political Change
}

\author{
Sławomir Ledwoń \\ Department of Urban Design and Regional Planning, Faculty of Architecture, Gdansk University of Technology, Gdansk 80-233, \\ Poland
}

\begin{abstract}
The aim of this paper is to present the development of shopping centres in Poland after its political transition. From that time, all types of shopping centres were built, starting from the very basic first generation and developing into the most current formats. In the article, types of shopping centres are compared to their western origins. Planning laws and procedures that apply to the processes are also described, with an example of a law that was introduced to specifically control growth of shopping centres. Apart from that current trends and growth possibilities in the present market situation are discussed. As a result, a very rapid development process was observed, with little hampering from the planning policies. This may be used as a point of reference for other countries that have not yet encountered that process.
\end{abstract}

Key words: Shopping centres, retail, planning laws, Poland, transformation.

\section{Introduction}

Shopping centres are one of the most vivid evidence of economical freedom [1,2]. Until the transformation trade and real estate in Poland was greatly limited. The abrupt political change allowed developers to realise contemporary retail schemes, which were eagerly accepted by customers. But always such changes arise tensions among the market players, including the owners of existing, traditional shops [3]. Not only the market, but also the space of Polish cities needed to adjust and absorb this new phenomenon. In such cases, regulations for planning new development are needed [4]. Often it is difficult to find balance between sometimes contradictory needs all actors - creating just but also firm rules for development.

As this phenomena is quite recent in Poland, there has not been much research done so far. Most of the architectural publications concern mainly description

Corresponding author: Sławomir Ledwoń, Ph.D., research fields: urban planning, retail planning, shopping centres, ICT in cities and planning education. E-mail: sled@pg.gda.pl. of the new projects, while there are none that thoroughly discuss the planning issues concerning retail development in the country. While most of the data available are statistical, allowing only for quantitative comparison.

This article describes the development of shopping centres in Poland with basic characteristics of its history, form and types. It analyses the relation between traditional and contemporary retail in terms of changes in the quantity and use of shop units. The changes in Polish laws concerning spatial planning and shopping centres are discussed. It is given that the development of shopping centres in Poland occurred in the last two decades it is a very good example for other countries that need such reform.

In the following section, the development of retail in Poland will be described, referring to the history of retail in post-socialist Poland as a background and defining the shopping centre generations. Later on, the next section describes the assessment of changes in retail structure that resulted from absorbing new formats. In the last section, planning laws concerning 
retailing structure are described. These serve as important framework for development.

\section{Development of Retail in Poland}

\subsection{History of Retail in Post-Socialist Poland}

Starting with the transformation in 1989, Poland has gone through very thorough changes. Retail has also changed and developed very rapidly [5]. Before that time, in socialised economy, retailing had been centrally planned, with $95 \%$ of retailing and entire wholesale in national hands [6]. Liberation of the market has dramatically changed the situation for selling goods. Abolishment of the monopoly allowed for freedom in pricing. Private owners immediately saw the opportunities to start new enterprises. Polish streets were literally swarmed with the most simple forms of retailing - stalls, booths and stands, that sometimes were very temporary and improvised, such as camp-beds [7].

In 1990, public sector had a share of $64 \%$ in total sales, whereas in 2002 it was reduced to only $2 \%$ [8]. The freedom of market has not only increased private ownership, but also invited foreign investors to expand in Poland. Apart from bringing their money, they also introduced their know-how and expertise in retail development. However, the gap between retailing in Poland and its western counterparts was estimated for 20-25 years [6]. The country was lacking modern shopping infrastructure and the rules for interaction on the market had to be developed. Nevertheless, new shopping opportunities, even though they were very simple, seemed innovative and fresh to the customer.

Since the transformation, retailing in Poland has gone through four major development stages [6]:

- 1990-1995-First years brought initial disintegration of the market, with the increase of number of shops. Hypermarkets, supermarkets and discount shops had a 5\% share in the market. Manufacturers were selling through their preferred wholesalers;
- 1996-2000-In this period retailing become more consolidated. Mass distribution improved, as well as the share of contemporary forms of shopping grew greater, thus lessening the importance of traditional shops. Manufacturers were selling through their wholesalers and also directly to retailers;

- 2001-2005-As more hypermarkets, supermarkets and discount shops were built the role of traditional retailing had lowered. Vertical integration became a visible trend in the network. Wholesalers were losing their importance, as there were less single retailers and the manufacturers were selling directly to the chain retailers. The market become more simplified-limiting the major actors to manufacturers, retailers and consumers. In this period, major retailers began to negotiate and even impose the prices on producers;

- 2005-2008-The market finally became mature in terms of modern retail space. Additional formats were introduced, such as convenience stores and discount shops based on the franchise model. In this period, specialisation was more visible, with entrepreneurs seeking new opportunities in satisfying more particular needs of the customers, e.g., eco food.

The visible growth of modern retail space area has begun in mid-1990s. Fig. 1 shows the supply of new retail space and the total area, based on Cushman and Wakefield data. The supply initially boosted, noticeably increasing year by year to nearly one million square metres in each of years 1999 and 2001. After that period, the market slowed down for two years, to gain speed once again after 2003. The following years have brought steady growth, which was hampered by economical crisis. Its results were visible in 2010 , with a delay typical for real estate projects-when less new shopping centre space was opened. Nevertheless, there has not been a major crash, and the situation remained steady in 2011 with the supply of around $700,000 \mathrm{~m}^{2}$ of new retail space. Currently developers have restarted some of the projects that were postponed due to the market situation. 


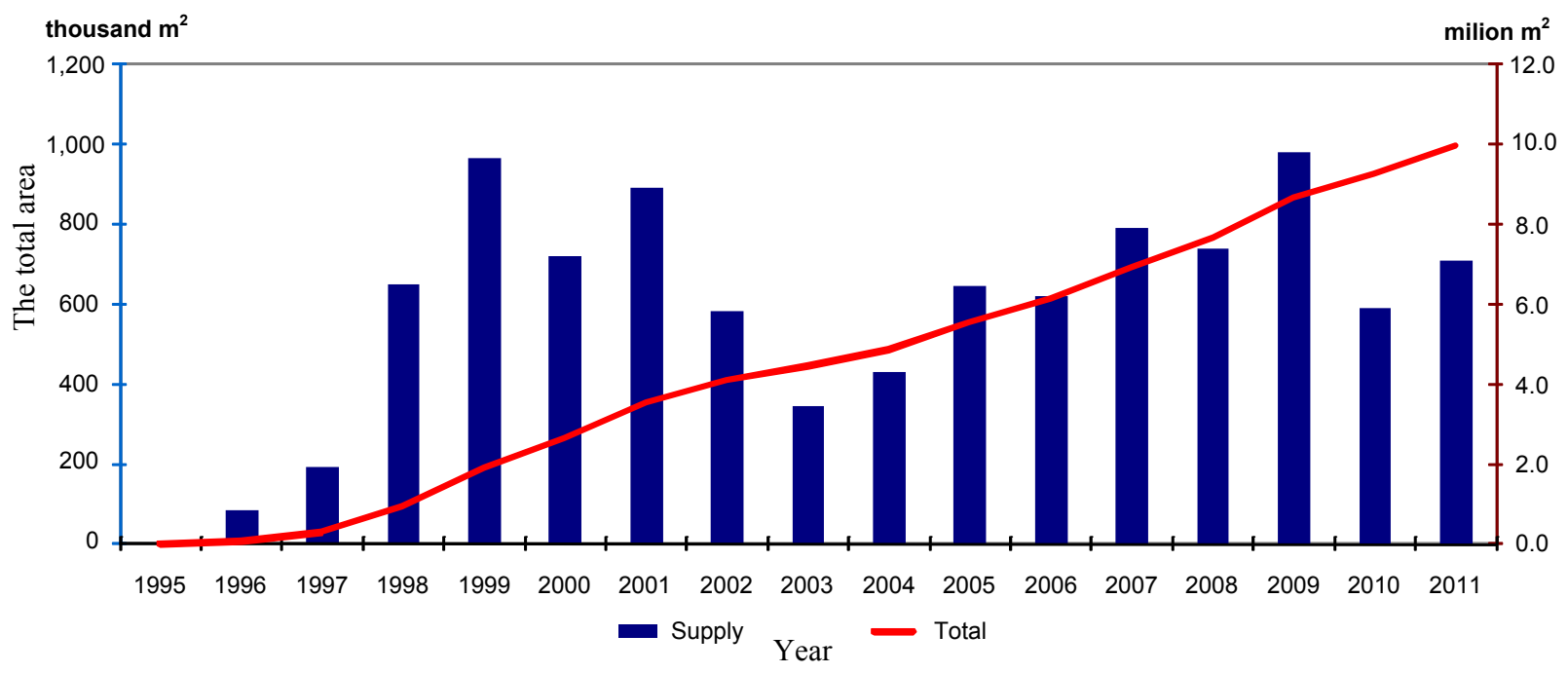

Fig. 1 Growth of modern retail space area in Poland (Cushman and Wakefield data).

At the moment around $800,000 \mathrm{~m}^{2}$ of new space is being constructed, and it is estimated that a similar amount will be opened in 2013 [9].

The analysis of shopping centre development in Poland brings two other observations [10,11]. First of all, hypermarkets are becoming less popular retail format among new developments. Their share in total floor space built dropped from $17 \%-29 \%$ in years $1998-2000$ to $5 \%-7 \%$ in $2005-2007$, giving room to shopping centres and retail warehouses. It was a result of gradually filling of the market and dividing it among largest players. Moreover, new shopping formats were introduced, that were more attractive to customers. Secondly, smaller cities are becoming more significant in developer activity. Between 1998 and 2008, the percent of GLA (gross leasable area) built outside the seven largest agglomerations in Poland has grown from approximately $20 \%$ to nearly $50 \%$.

In $2011,53 \%$ of total floor space was built in city centres, extensions of existing schemes amounted for $20 \%$ of new space. Thirty-one percent of the supply was located in cities smaller than 100,000 inhabitants. It is estimated that this share will grow to $45 \%$ in 2012. Small and medium centres are most popular among all new projects- $72 \%$ of shopping centres planned to be opened this year do not exceed 40,000 $\mathrm{m}^{2}$ [12].
According to Cushman and Wakefield [9, 13], at the end of 2011 there was around 11 million $\mathrm{m}^{2}$ of total GLA in Poland. There is still room for new investment. The average GLA per 1,000 inhabitants in 27 European Union Countries is around $240 \mathrm{~m}^{2}$. In Poland, this factor is still below $200 \mathrm{~m}^{2}$, which gives us 22nd place among all European countries. But the size of Polish centres in pipeline places us on the 6th position, with Russia noticeably leading with impressive 3 million $\mathrm{m}^{2}$ to be built.

\subsection{Generations of Shopping Centres}

The above analysis concentrates on the quantitative growth of shopping centres, whereas in terms of analysing the build form of cities - other factors are important as well. In case of shopping centres, a term generation is often used to describe their complexity, architectural form, location and functional diversity $[14,15]$. In case of Polish shopping centres these generations may be defined as follows $[16,17]$.

The first generation is the most simple and archetypical. The shopping centre consists mainly of the hypermarket with its area up to $70 \%$ of the total, which is aided by some smaller shops formed as a strip gallery. These are located mainly outside city centres, on the suburbs, where car access is easy and land values are relatively low. Architecture is not very 
complicated. Mostly, they have one story space enclosed in a uniform cladding, with the design typical for the unique retail group, which mostly is the owner of the centre, and surrounded by a vast car park. Polish examples this generation are, among others, Auchan in Gdańsk and Tesco Połczyńska in Warsaw.

The second generation is similar in concept to the previous, although the form is more complex and programme larger and more complex. As they are located on more urbanised land, they usually have two retail stories and most often a multilevel parking. The hypermarket has less share in total area, around $30 \%-40 \%$, as the number of smaller shops grows and larger retailers are introduced as key tenants. Some of those buildings are still owned by the retail chain, as for example Carrefour in Gdańsk-Morena.

The third generation is built in dense urban areas and the main difference with the preceding one is the addition of entertainment and leisure uses. It means not only larger food courts with, but most of all other tenants such as sports centres and gyms, cinema multiplexes, bowling arenas, etc.. Leisure is an important factor attracting customers allowing them to relax and spend their free time not only on shopping. Their architecture reflects the need to fit in the urban context and is more complex. Some of these buildings are recognised for their high quality-for example Galeria Bałtycka in Gdańsk has received the ICSC European Shopping Center Award in the category of "New Developments: Large" in 2009.

Fourth is the most contemporary shopping centre generation in Poland. Apart from leisure uses typical for the third generation, in this group other functions are added-e.g., offices, hotels and conference centres. Scarcely these are typical projects. Most of them incorporate existing buildings and urban tissue, often with regards to redevelopment of brown field areas. As a result, these are flagship projects for their developers, with recognisable and high quality architecture and urban design, often covering extensive areas. Such is an example of Manufaktura in
Łódź, which is a redevelopment of post-industrial site, including Andel's Hotel and cultural complex consisting of museums and theatre.

So far, the last generation, fifth, has not yet been built in Poland, but already has been successfully realised abroad. In this case, the centre is supported by dwellings - flats, apartments, condominiums, dormitories, etc. and often organised in a more open form (without fully enclosed walkways). These are mixed use compositions, rather than pure shopping centres, where the retail function seems to be a complimentary addition to the whole project. It is difficult to reconcile all these uses in one structure, so they are spread on several of buildings. What is important feature of such developments is that they serve as "a city within a city", allowing its inhabitants to realise their needs within the project area. Nevertheless, it should be noted that the catchment area of the shopping centre itself exceeds the development area, therefore such shopping centre still needs neighbouring citizens as customers. Such centres were planned in projects such as Young City (which at the moment postponed) and Garnizon in Gdańsk. An open scheme, but without the housing component, will be built at Hay Market and Crawfish Market in Gdańsk.

The above division into generations is very general and sometimes the boundaries are not clear. It should be stressed that while the first examples of generations were built in chorological order, nowadays the primary generations are still being built, although not so extensively. Moreover, it is possible for an existing centre to advance in the list, mostly by realising additional programme and refurbishing the existing scheme.

\section{Changes in Retailing Structure-Absorbing New Formats}

The development of shopping centres relates not only to those objects, their form and popularity, but also to their interaction with other retail outlets, 
especially those that are called "traditional" shops.

The impact of shopping centres on traditional retailing has been a hotly debated issue ever since the first new formats were built, not only in Poland [9] - whether and how their development should be controlled, planned or even in some cases banned. The main concern was that contemporary retailing is a threat to conventional shops that will eventually go bankrupt due to strong competition and lack of customers. Other arguments against shopping centres concerned the impact on transportation system. Some traditionalists were speaking about the growing significance of foreign investment in Poland, with respect to its independence. Others were discussing the social aspect of changing customer behaviour and consumerism $[18,19]$.

In Poland, there is not much clear evidence gathered on the impact of shopping centres on traditional retail. Analyses of retail structure are rarely published. Central Statistical Office (GUS-Główny Urząd Statystyczny) is collecting various data, but it is not detailed enough in terms of spatial location for an accurate examination. Some data were gathered in the paper [11]. Two Polish cities, Gdynia and Łódź, were analysed among others.

The analysis aggregated the number of units and calculated their share, in division on basic types of operation: mixed, grocery, FMCG (fast-moving consumer goods) other than groceries, clothing, interior design, culture and sport, gastronomy, leisure and all other. Therefore, these data include also service units that are tenants in shopping centres and high streets. The results of this analysis are shown in Table 1 and Fig. 2.

In order to give a point of reference situation in Poland was analysed. Based on data provided by Central Statistical Office, the total number of nearly 530,000 units in 1998 has dropped significantly by $8 \%$ in 2005 to 485,000 . This was mainly a result of decrease in number of mixed and grocery shops by $18 \%$ and $19 \%$, respectively, although their share in the total has remained at a similar level - in both cases $33 \%$ in 1998 and $33 \%$ in 2005. There was a significant growth by $16 \%$ in the FMCG non-grocery

Table 1 Number and share of units in retailing structure [11, 20-22].

\begin{tabular}{|c|c|c|c|c|c|c|c|c|c|c|c|}
\hline & \multicolumn{3}{|c|}{ Poland } & \multicolumn{4}{|c|}{ Gdynia } & \multicolumn{4}{|c|}{ Łódź } \\
\hline & $\begin{array}{l}\text { Country } \\
\text { total }\end{array}$ & $\begin{array}{l}\text { Country } \\
\text { total }\end{array}$ & \begin{tabular}{|l|} 
Galeria \\
Bałtycka \\
shopping \\
centre
\end{tabular} & $\begin{array}{l}\text { City } \\
\text { centre }\end{array}$ & $\begin{array}{l}\text { City } \\
\text { centre }\end{array}$ & \begin{tabular}{|l} 
City \\
centre + \\
shopping \\
centres
\end{tabular} & $\begin{array}{l}\text { Shopping } \\
\text { centres }\end{array}$ & \begin{tabular}{|l|} 
Piotrkowska \\
Street
\end{tabular} & \begin{tabular}{|l|} 
Piotrkowska \\
Street
\end{tabular} & $\begin{array}{l}\text { Piotrkowska } \\
\text { Street + } \\
\text { shopping } \\
\text { centres } \\
\end{array}$ & $\begin{array}{l}\text { Shopping } \\
\text { centres }\end{array}$ \\
\hline Year & 1998 & 2005 & 2008 & 1998 & 2008 & 2008 & 2008 & 2003 & 2007 & 2007 & 2007 \\
\hline Mixed & $\begin{array}{l}174,701 \\
33 \%\end{array}$ & \begin{tabular}{|l}
143,662 \\
$30 \%$
\end{tabular} & - & - & - & - & - & - & - & - & - \\
\hline Grocery & \begin{tabular}{|l|}
177,321 \\
$33 \%$ \\
\end{tabular} & \begin{tabular}{|l|}
143,474 \\
$30 \%$
\end{tabular} & \begin{tabular}{|l|}
8 \\
$4 \%$ \\
\end{tabular} & $\begin{array}{l}227 \\
9 \% \\
\end{array}$ & $\begin{array}{l}184 \\
8 \%\end{array}$ & $\begin{array}{l}190 \\
8 \%\end{array}$ & \begin{tabular}{|l|}
6 \\
$3 \%$ \\
\end{tabular} & \begin{tabular}{|l|}
42 \\
$3 \%$ \\
\end{tabular} & \begin{tabular}{|l|}
65 \\
$4 \%$ \\
\end{tabular} & \begin{tabular}{|l|}
79 \\
$4 \%$ \\
\end{tabular} & \begin{tabular}{|l|}
14 \\
$3 \%$ \\
\end{tabular} \\
\hline FMCG other & \begin{tabular}{|l|}
7,078 \\
$1 \%$ \\
\end{tabular} & $\begin{array}{c}8,211 \\
2 \% \\
\end{array}$ & \begin{tabular}{|l|}
9 \\
$5 \%$ \\
\end{tabular} & \begin{tabular}{|l|}
93 \\
$4 \%$ \\
\end{tabular} & \begin{tabular}{|l|}
63 \\
$3 \%$ \\
\end{tabular} & \begin{tabular}{|l|}
73 \\
$3 \%$ \\
\end{tabular} & \begin{tabular}{|l|}
10 \\
$6 \%$ \\
\end{tabular} & \begin{tabular}{|l|}
15 \\
$1 \%$ \\
\end{tabular} & \begin{tabular}{|l|}
15 \\
$1 \%$ \\
\end{tabular} & \begin{tabular}{|l|}
31 \\
$2 \%$ \\
\end{tabular} & \begin{tabular}{|l|}
16 \\
$4 \%$ \\
\end{tabular} \\
\hline Clothing & \begin{tabular}{|l|}
48,324 \\
$9 \%$ \\
\end{tabular} & \begin{tabular}{|l|}
52,456 \\
$11 \%$ \\
\end{tabular} & \begin{tabular}{|l|}
102 \\
$53 \%$ \\
\end{tabular} & \begin{tabular}{|l|}
472 \\
$19 \%$ \\
\end{tabular} & \begin{tabular}{|l|}
379 \\
$16 \%$ \\
\end{tabular} & \begin{tabular}{|l|}
434 \\
$17 \%$ \\
\end{tabular} & \begin{tabular}{|l|}
55 \\
$31 \%$ \\
\end{tabular} & \begin{tabular}{|l|}
171 \\
$14 \%$ \\
\end{tabular} & $\begin{array}{l}142 \\
9 \% \\
\end{array}$ & \begin{tabular}{|l|}
356 \\
$18 \%$ \\
\end{tabular} & \begin{tabular}{|l|}
214 \\
$49 \%$ \\
\end{tabular} \\
\hline $\begin{array}{l}\text { Interior } \\
\text { design }\end{array}$ & $\begin{array}{l}14,900 \\
3 \%\end{array}$ & \begin{tabular}{|l|}
15,167 \\
$3 \%$
\end{tabular} & \begin{tabular}{|l|}
13 \\
$7 \%$ \\
\end{tabular} & $\begin{array}{l}132 \\
5 \%\end{array}$ & $\begin{array}{l}121 \\
5 \%\end{array}$ & $\begin{array}{l}134 \\
5 \%\end{array}$ & $\begin{array}{l}13 \\
7 \% \\
\end{array}$ & $\begin{array}{l}72 \\
6 \% \\
\end{array}$ & \begin{tabular}{|l|}
51 \\
$3 \%$ \\
\end{tabular} & \begin{tabular}{|l|}
77 \\
$4 \%$ \\
\end{tabular} & \begin{tabular}{|l|}
26 \\
$6 \%$ \\
\end{tabular} \\
\hline $\begin{array}{l}\text { Culture and } \\
\text { sport }\end{array}$ & \begin{tabular}{|l|}
16,217 \\
$3 \%$ \\
\end{tabular} & \begin{tabular}{|c|}
8,342 \\
$2 \%$ \\
\end{tabular} & \begin{tabular}{|l|}
28 \\
$14 \%$ \\
\end{tabular} & $\begin{array}{l}137 \\
6 \% \\
\end{array}$ & $\begin{array}{l}102 \\
4 \% \\
\end{array}$ & $\begin{array}{l}122 \\
5 \% \\
\end{array}$ & \begin{tabular}{|l|}
20 \\
$11 \%$ \\
\end{tabular} & \begin{tabular}{|l|}
125 \\
$10 \%$ \\
\end{tabular} & $\begin{array}{l}103 \\
7 \% \\
\end{array}$ & $\begin{array}{l}155 \\
8 \% \\
\end{array}$ & \begin{tabular}{|l|}
52 \\
$12 \%$ \\
\end{tabular} \\
\hline Gastronomy & \begin{tabular}{|l|}
70,318 \\
$13 \%$ \\
\end{tabular} & \begin{tabular}{|l|}
91,150 \\
$19 \%$ \\
\end{tabular} & \begin{tabular}{|l|}
16 \\
$8 \%$ \\
\end{tabular} & \begin{tabular}{|l|}
88 \\
$4 \%$ \\
\end{tabular} & $\begin{array}{l}137 \\
6 \% \\
\end{array}$ & $\begin{array}{l}158 \\
6 \% \\
\end{array}$ & \begin{tabular}{|l|}
21 \\
$12 \%$ \\
\end{tabular} & \begin{tabular}{|l|}
104 \\
$8 \%$ \\
\end{tabular} & $\begin{array}{l}125 \\
8 \% \\
\end{array}$ & \begin{tabular}{|l|}
197 \\
$10 \%$ \\
\end{tabular} & \begin{tabular}{|l|}
72 \\
$16 \%$ \\
\end{tabular} \\
\hline Leisure & 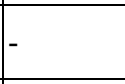 & - & \begin{tabular}{|l|}
3 \\
$2 \%$ \\
\end{tabular} & \begin{tabular}{|l|}
79 \\
$3 \%$ \\
\end{tabular} & $\begin{array}{l}105 \\
4 \% \\
\end{array}$ & $\begin{array}{l}112 \\
4 \% \\
\end{array}$ & \begin{tabular}{|l|}
7 \\
$4 \%$ \\
\end{tabular} & \begin{tabular}{|l|}
85 \\
$7 \%$ \\
\end{tabular} & $\begin{array}{l}106 \\
7 \% \\
\end{array}$ & $\begin{array}{l}117 \\
6 \% \\
\end{array}$ & \begin{tabular}{|l|l|}
11 \\
$3 \%$ \\
\end{tabular} \\
\hline Other & \begin{tabular}{|l|}
20,728 \\
$4 \%$ \\
\end{tabular} & \begin{tabular}{|l|}
23,030 \\
$5 \%$
\end{tabular} & \begin{tabular}{|l|}
15 \\
$8 \%$
\end{tabular} & $\begin{array}{l}1,200 \\
49 \%\end{array}$ & $\begin{array}{l}1,255 \\
53 \%\end{array}$ & $\begin{array}{l}1,303 \\
52 \%\end{array}$ & \begin{tabular}{|l|}
48 \\
$27 \%$
\end{tabular} & \begin{tabular}{|l|}
639 \\
$51 \%$ \\
\end{tabular} & \begin{tabular}{l|}
926 \\
$60 \%$ \\
\end{tabular} & $\begin{array}{l}960 \\
49 \% \\
\end{array}$ & \begin{tabular}{|l|}
34 \\
$8 \%$ \\
\end{tabular} \\
\hline Total & \begin{tabular}{|l|}
529,587 \\
$100 \%$ \\
\end{tabular} & \begin{tabular}{|l|}
485,492 \\
$100 \%$
\end{tabular} & $\begin{array}{l}194 \\
100 \%\end{array}$ & \begin{tabular}{|l|}
2,428 \\
$100 \%$ \\
\end{tabular} & $\begin{array}{l}2,346 \\
100 \%\end{array}$ & $\begin{array}{l}2,526 \\
100 \%\end{array}$ & $\begin{array}{l}180 \\
100 \% \\
\end{array}$ & $\begin{array}{l}1,253 \\
100 \%\end{array}$ & \begin{tabular}{|l|}
1,533 \\
$100 \%$
\end{tabular} & $\begin{array}{l}1,972 \\
100 \% \\
\end{array}$ & \begin{tabular}{|l|}
439 \\
$100 \%$ \\
\end{tabular} \\
\hline
\end{tabular}


shops number, as well as $9 \%$ increase in clothing shops, with change of their share in total from $9 \%$ to $11 \%$. The above was a result of market consolidation as well as emerging new retailing formats. For comparison, an exemplary shopping centre Galeria Bałtycka in Gdańsk was analysed. Fifty-three percent of its 194 tenants in 2008 were selling clothing, while there were only eight grocery shops and nine other FMCG outlets.

Retail structure in Gdynia was studied in 1998 by Tarkowski [20] and again in 2008 by the author [11]. All units in the downtown area were catalogued. In this 10-year span, four shopping centres were built with total floor space of $39,000 \mathrm{~m}^{2}$, which is not a large number compared to other cities. In this term, the influence of shopping centres in this case is less visible. Between 1998 and 2008, the number of units outside shopping centres has dropped only by $3 \%$, while the total including shopping centres grew by $5 \%$ to 2,526 units. The changes in the number of traditional units were in FMCG non-grocery (-32\%), clothing $(-20 \%)$, grocery $(-19 \%)$ sectors with growth in gastronomy $(56 \%)$ and leisure $(33 \%)$ sectors. When analysing the share of the above, no major changes were observed. The share of clothing shops dropped from $19 \%$ to $16 \%$, while the percent other units grew from $49 \%$ to $53 \%$. The above changes reflect the tendencies for Poland at that time. Świętojańska Street, which is the high street in Gdynia, remained a shopping destination for customers, although some specialisation of the units is visible. In the coming years, this process may be intensify, as one of the shopping centres is currently being extended by additional $50,000 \mathrm{~m}^{2}$.

A clearly visible impact of modern shopping on traditional retail, Piotrkowska Street, has been identified in Łódź. According to the data collected by the local authorities [21, 22] between 2003 and 2007, there has been a major change in the profile of the high street. Although the total number of units grew

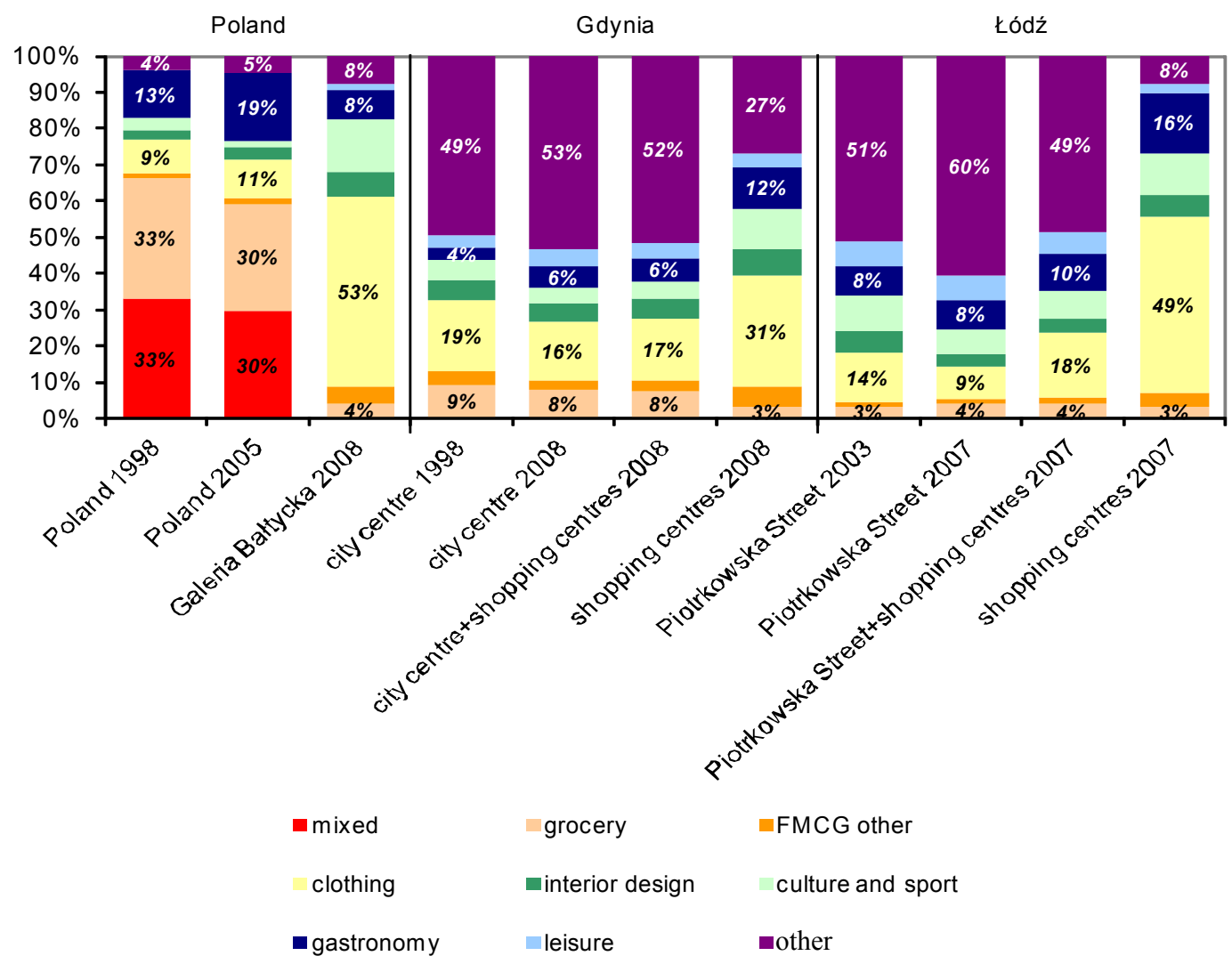

Fig. 2 Share of units in retailing structure [10, 20-22]. 
from 1,253 in 2003 to 1,533 in 2007 , the share of clothing shops dropped by $5 \%$ points (from $14 \%$ to $9 \%$ ), giving room to growing number of other units (change in share from $51 \%$ to $60 \%$ ). Piotrkowska became more "a banking street" with more additional other service units that are less popular by customers. This was a result of building large shopping centres (in 2002 and 2006), with additional floor space equal to $39 \%$ of the commercial floor space along Piotrkowska Street. This added 439 new shops to the whole system ( $22 \%$ of the total). Nowadays customers prefer to spend time in the two high quality shopping centres-Galeria Łódzka and Manufaktura, rather than the city's public space, although some actions are being taken in order to revive the high street.

\section{Planning Laws Concerning Retail}

It is not possible to analyse the changes in spatial development concerning new retail formats without proper understanding of the planning regulations and background behind this process.

\subsection{General Planning Laws in Poland}

Planning law in Poland underwent major changes in 1994 and then in 2003, to better reflect the needs of new market. The government is divided into four tiers: national, voivodship (województwo), county (powiat) and local-communal (gmina), with planning competences on all levels, except counties. Central government is responsible for the National Spatial Arrangement Policy (koncepcja przestrzennego zagospodarowania kraju) and national regulation, ordinance and acts of law. Voivodships prepare Voivodship Spatial Management Plans (plan zagospodarowania przestrzennego województwa) and other studies. Counties do not draft plans, but are in charge of issuing building permissions and building inspections. The detailed planning for development is actually done at local level by communes [23].

Communes are required to draft a Communal Study of Conditions and Directions of the Spatial Plan (studium uwarunkowań i kierunków zagospodarowania przestrzennego gminy), which has the cover the area of the whole commune. Its scope sets the leading land use and basic parameters; development corridors; protection of farming and forest areas; other areas of protection and building prohibition; compulsory planning areas and guidelines for other matters. It sets regulations for the spatial development of the commune, but is not legally binding for the development.

The document that is actually regulating new development is Local Area Development Plan (miejscowy plan zagospodarowania przestrzennego). It is also drafted by the commune and is a local law for issuing building permissions. It sets the specific land uses with exact building parameters; rules for environmental, natural and cultural protection; infrastructure and accessibility; and other regulations. It covers a part of the commune region, most often the area planned for development or neighbourhoods. It is subject to an administrative procedure, public hearings and agreements with other parties. Usually plots are not required to have such local plan, unless it is stated so in the communal study. Each enacted plan has to be coherent with the regulations of communal study, which is the only possibility of spatial implementation of the latter.

In case when there is no Local Area Development Plan, a simplified planning tool has been introduced in order to allow for uncomplicated development. These are planning decisions called Conditions of Development and Spatial Management (decyzja o warunkach zabudowy i zagospodarowania terenu). They are administrative documents, which are issued based on the examination of existing buildings in the surroundings and conformity of the proposal with other regulations. The general principle is to allow development that is consistent with the existing uses and matches the general built form parameters of the neighbourhood. This planning decision is initiated only with the investor's proposal and then sets rules 
for issuing building permission accordingly.

\subsection{Retail Planning}

In the current planning framework special rules for retail development have also been set. First of all, there is no definition of a shopping centre in the Polish law. Nevertheless, retail objects are treated differently from other buildings when their total sales area exceeds $2,000 \mathrm{~m}^{2}$. Sales area is defined in planning law as the direct trading area, not including the additional space for storage, offices, services, etc.. Therefore, it is not equivalent to the most common shopping centre attribute-GLA.

Locations for shopping centres with the sales area over $2,000 \mathrm{~m}^{2}$ are required to be set in the Communal Study of Conditions and Directions of the Spatial Plan. Subsequently, they should be also designated in Local Area Development Plans, which have to comply with the communal study. In this case, all such development is meant to be designed upon a valid local plan. The existing law does not require any additional studies to be prepared, such as impact assessment on existing retail and local economy. Of course, the commune may prepare any additional analysis voluntary, but that does not happen often. Nevertheless, both procedures, for the study and local plan, are subject to public hearings and agreements with other authorities.

Apart from the environmental impact assessment of the above planning projects, both the study and the local plan, additional environmental impact assessment procedure might be needed for some shopping centres. It is required by environmental laws, after determining if the planned centre would have a potential environmental impact. This course of action is carried out for centres of total usable floor area above $5,000 \mathrm{~m}^{2}$ in environmentally sensitive zones, and $20,000 \mathrm{~m}^{2}$ outside these regions. It should be noted that this area is a different parameter than GLA and sales area and that the environmental procedure is a separate part of the investment process.
The previous planning law from 1994 was to some extent different from the above. There was a requirement to formulate an assessment of the impact of the planned retail scheme on labour market, communication and transport infrastructure, existing retail system as well as the needs and interests of consumers. The above borderline sales area of shopping centres was differentiated according to the size of the commune. In settlements smaller than 20,000 inhabitants, it was lowered from $2,000 \mathrm{~m}^{2}$ to only $1,000 \mathrm{~m}^{2}$. After the reform in 2003, this requirement was abolished as an unnecessary obstacle to new development.

Most usually, the communal studies do not include detailed locations of shopping centres or a complex strategy for retail development. Therefore, often they are amended to match the needs of a certain project, which means undergoing the whole planning procedures for these documents. These actions of local government are not distinctive only for the retail schemes. In times of the most rapid growth in the property market, other developments were planned in such a way, to match the demand for new investment.

Theoretically, it is possible to issue a planning decision for a shopping centre, given that there is no local plan and that there is an existing retail scheme in the surrounding area. Therefore, it is scarcely used for planning new development, but rather for extensions or refurbishment of the existing centres. What is noteworthy is that in such situation the procedure is much quicker than in case the of a local plan - a few months rather than at least a year. It is without public hearings (with the right to comment limited only to the adjacent neighbours) and without the basic impact assessment. Moreover, the agreements with other authorities are limited by law to only a very few of them. On one hand, it simplifies the planning process a lot, but on the other does not give the power to the local government to refuse a planning decision, unless it would be against the law. 


\subsection{Retail Law of 2007}

In 2007, the Polish government has passed an additional law that individually concerned retail schemes [10]. This law was meant to "protect the public benefit and impose sustainable development" allocating more power to the government in terms of shopping structure growth and protecting the existing retail structure. It introduced a definition of large scale retail scheme $(\mathrm{WOH}$-wielkopowierzchniowy obiekt handlowy), meaning any scheme with sales area exceeding $400 \mathrm{~m}^{2}$. Although this was an initiative meant to satisfy the public opinion, it met with substantial opposition and critique from the real estate market, eventually leading to abolishing this law a year later.

The WOH law has amended the 2003 planning law by lowering the limit for special planning procedure from $2,000 \mathrm{~m}^{2}$ to $400 \mathrm{~m}^{2}$ of sales area. Therefore, this created the need to adjust existing communal studies to include smaller retail projects than before those between $400 \mathrm{~m}^{2}$ and $2,000 \mathrm{~m}^{2}$, which were not required to be previously included. Any local plan for such scheme drafted after the WOH law would be in contradiction to the communal study and could not be passed as local law.

Another requirement for shopping centre development was introduced. Each construction of new large scale retail scheme required additional permission issued by the mayor. It had to be consulted with the town council and consistent with the communal study. In case of schemes larger than 2,000 $\mathrm{m}^{2}$, it also had to be non conflicting the voivodship plan and received a positive consultation of viovodship parliament. This created problems that voivodship plans were rather not extensive in detailed retail development and that the parliament was not previously involved in planning at a local level. Moreover, this could lead to a situation, when the mayor with local government would pass a local plan allowing for a shopping centre and then perhaps have obligations to the same investment as part of the
WOH law procedure.

The most important component of the permission process set by WOH law concerned the impact analysis of new development. It had to examine its possible influences on infrastructure, local road system, local labour market, existing urban relations, existing retail system, including other $\mathrm{WOH}$ schemes, and impact on natural environment. This should have been performed by local authorities. Detailed governmental requirements for such analysis were to follow this law, but eventually never did. Another questionable factor was that it was allowed to attach such analysis by the developer to their planning application, which casted doubts on its independency and objectivity.

But there should be a positive element of this law outlined as well. All the schemes were required to issue detailed information about their projects both planned as well as existing. Previously such information was not required. Owing to such regulations local government was allowed to gather data, that could be used for future planning purposes and monitoring changes in the retail system.

In 2008, the Constitutional Tribunal has ruled that the WOH law was transgressing the Polish Constitution and this law was abolished, mainly due to unfair limitations in economical freedom. In the meantime developers put on hold most of their new project, waiting for this resolution, because the $\mathrm{WOH}$ law was supposed to be unconstitutional from the very beginning. Nevertheless, the law seems to have been good in principles, trying to give more power to the local government in influencing the retail system and providing them tools for analysis and planning future development.

But there were also other downsides of the $\mathrm{WOH}$ law. First of all, it was introduced too late, when the core retail system was already built and the most influences on the existing situation already had happened. Secondly, the threshold was set too low, meaning that buildings not meant to be analysed and 
not potentially harmful were included. Such were for example medium furniture departments, groups of small shops being a part of housing that assembled together exceeded $400 \mathrm{~m}^{2}$. Finally the law was prepared too hastily and the rules were not clear enough to provide a just, but also firm retail planning tool.

\section{Conclusions}

The case of shopping centre development in Poland is a very good example of its evolution, planning and absorption of new investment in a nutshell. At the beginning of 1990s, there was no modern shopping, but nowadays Poland is building the most current formats and the market is gradually becoming saturated up with retail space. The gap between Polish shopping centres and their western counterparts has quickly been filled. Nevertheless, such abrupt changes create tensions and problems in planning and managing their growth.

The analysis of Polish case proves that it is difficult to quickly react to fast changes and adjust law framework and planning models accordingly. At the beginning, after the transformation, new investment was so eagerly welcomed that not always a proper analysis of possible impact was made. And that includes all new development, not only retail. Shopping centres bring both threats (impact on existing retail, transportation, urban form, public space, emptying city centres) as well as new opportunities, especially to the customers (variety in shopping offer, better prices resulting from competition, urban regeneration). It is difficult to set a clear borderline for governmental interference with the free market, especially in a country with socialist history. But obviously spatial planning and development of urban structures should be controlled.

In Polish law, there are certain rules set for shopping centre location, although they are not subject to thorough analysis and studies of retail structure. They are quite relaxed compared to other countries, therefore, some developments were not wisely and well planned, lacking impact assessment. Some changes in space cannot be reversed. The WOH law was introduced too late, after the most growth had already occurred. It also had several flaws that brought to its final abolishment. Such laws should give transparent rules for decision making. Retail structure should be planned as a whole, beginning at a regional level and with detailed regulations at local level. There is a need for compulsory, comprehensive regional retail studies covering more than one commune, especially in metropolitan agglomerations. The thresholds for special planning rules should be set accordingly to the size of the city or whole conurbation, because there is a need to lower these limits in smaller towns.

In the current, uncertain times developers are not eager to take risks, but still are investing and building new shopping centres in Poland. As the market will improve new tendencies are to emerge. They include building open and mixed use schemes with substantial amount retail floor space. Nowadays, smaller centres and shops, such as discount stores, are also being built, while virtual shopping and internet purchases are also more popular. Expansion and refurbishment of existing structures is inevitable, as the market competition is getting stronger. Eventually, if too much retail space is built, it may even lead to a situation when some centres will have to close and become dead malls, like in America.

Well planned downtown shopping centres can help to strengthen city centres and make them attractive to customers again, thus contributing to the principles of smart growth and sustainability. With new funds, they bring new quality and fresh ideas that should not be hindered. These are opportunities for authorities to build on this potential and direct it towards a better built form of our cities.

\section{Acknowledgments}

This paper was first delivered to the 48th ISOCARP 
Congress "Fast Forward: Planning in a (Hyper) Dynamic Urban Context”, Sep. 10-13, 2012 in Perm, Russia.

\section{References}

[1] R. Koolhaas, S. Boeri, S. Kwinter, N. Tazi, H.U. Obrist, Shopping, Harvard Project on the City, Architecture, Design \& Contemporary Art Books, Barcelona, 2001.

[2] H. Stewart, Retailing in the European Union, Structures, Competition and Performance, Psychology Press, Routledge, 2003.

[3] M. Gałkowski, Why Polish downtowns may lose against shopping centres?, in: City within a City: Problems of Composition Conference Materials, Wydawnictwo Politechniki Krakowskiej, Cracow, 2004.

[4] C. Guy, Controlling new retail spaces: The impress of planning policies in western Europe, Urban Studies 35 (1998) 5-6.

[5] T. Domański, Strategies of Retail Development, Polskie Wydawnictwo Ekonomiczne, Warsaw, 2005.

[6] M. Kosicka-Gębska, M. Tul-Krzyszczuk, J. Gębski, Food Retail in Poland, Wydawnictwo SGGW, Warsaw, 2011.

[7] A. Taraszkiewicz, Polish shopping centres - Opportunities and threats for city space, in: L. Piotr, R.P. Elżbieta (Eds.), Commercialisation of Space-Diagnosis of the Phenomenon, Urbanista, Warsaw, 2008.

[8] W. Wilk, The place of cities in retail networks - Polish example, Prace i Studia Geograficzne 35 (2005) 129-153.

[9] Cushman \& Wakefield, Marketbeat, Polish Real Estate Market report[Online], 2012, www.cushwake.com (accessed July 13, 2012).

[10] S. Ledwoń, Shopping centres in Polish cities-Diagnosis of the phenomenon, in: L. Piotr, R.P. Elżbieta (Eds.), Commercialisation of Space-Diagnosis of the Phenomenon, Urbanista, Warsaw, 2008.
[11] S. Ledwon, The impact of shopping centres on downtowns, Ph.D. Thesis, Gdansku University of Technology, 2008.

[12] Jones Lang LaSalle Pulse, Retail Market in Poland in 2011[Online], www.galeriehandlowe.pl (accessed July 13, 2012).

[13] Cushman \& Wakefield, Marketbeat, Development of Shopping Centre Real Estate in Europe[Online], Sep. 2011, www.propertynews.pl (accessed July 13, 2012).

[14] G. Cliquet, Retailing in western Europe - Structures and development trends, in: Z. Joachim (Ed.), Handbuch Handel, Gabler Verlag, 2006.

[15] P. Coleman, Shopping Environments: Evolution, Planning and Design, Architectural Press, Oxford, 2006.

[16] Kalinowska Beata, We Are Waiting for Fifth Generation of Shopping Centres[Online], www.rp.pl (accessed May 23, 2008).

[17] S. Ledwoń, Retail-led redevelopment of downtown areas, in: L. Piotr, M.P. Justyna (Eds.), Selected Issues of City Revitalisation, Urbanista, Gdańsk, 2009.

[18] P. Underhill, Why We Buy: The Science of Shopping, MT Biznes, Cracow, 2001.

[19] M. Krajewski, Consumption and contemporaneity: About a certain perception of understanding social world, Culture and Society 41 (3) (1997) 3-24.

[20] M. Tarkowski, Spatial changes in services distribution in Gdynia downtown in 1980-1998, M.Sc. Thesis, Gdansk University, 1999.

[21] Strategies and Analysis Department, Łódź City Hall (WSiAUMŁ 2003) Functions of Piotrkowska Street, 2003.

[22] Strategies and Analysis Department, Łódź City Hall (WSiAUMŁ 2007) Functions of Piotrkowska Street, 2007.

[23] S. Ledwoń, Planning large scale projects in European spatial planning systems, in: L. Piotr, M.P. Justyna (Eds.), Planning and Execution of Urban Development, Akapit DTP, Gdańsk, 2011. 